\title{
PENGARUH KEIKUTSERTAAN SISWA DALAM BIMBINGAN BELAJAR DAN EKSTRAKURIKULER TERHADAP PRESTASI BELAJAR MATEMATIKA
}

\author{
Karim
}

\begin{abstract}
Abstrak
Prestasi belajar merupakan suatu kemampuan atau keberhasilan belajar individu terhadap materi yang dipelajari, terlihat dari adanya perubahan baik yang bersifat kognitif, afektif, maupun psikomotor. Untuk dapat meningkatkan prestasi belajar matematika siswa, maka diperlukan usaha untuk mencapai tujuan tersebut.Tujuan penelitian ini adalah untuk mengetahui pengaruh bimbingan belajar dan kegiatan ekstrakurikuler terhadap prestasi belajar matematika siswa.

Metode penelitian yang digunakan adalah metode deskriptif. Populasi dari penelitian ini adalah siswa SMA Negeri 2 Banjarmasin kelas XI Jurusan IPA sebanyak 144 orang dan Jurusan IPS sebanyak 155 orang. Sampel yang digunakan adalah sampel total.

Hasil penelitian menunjukkan bahwa untuk kelas $\mathrm{XI}$ Jurusan IPA model regresi yang diperoleh adalah $\hat{y}=43,11+$ 5,07 eskul $+19,94$ bimbel, sedangkan untuk kelas XI Jurusan IPS model yang regresi yang diperoleh adalah $\hat{y}=39,29+$ 26,17 eskul + 5,09 bimbel. Hasil ini menunjukkan bahwa baik kelas XI Jurusan IPA maupun Kelas XI Jurusan IPS, kegiatan ekstrakurikuler (eskul) dan bimbingan belajar (bimbel) mempunyai pengaruh positif yang signifikan terhadap prestasi belajar matematika siswa.
\end{abstract}

Kata Kunci: prestasi belajar matematika, bimbingan belajar, ekstrakurikuler

\section{Pendahuluan}

Salah satu komponen utama Kurikulum Tingkat Satuan Pendidikan (KTSP) adalah struktur dan muatan KTSP. Muatan KTSP meliputi sejumlah mata pelajaran yang keluasan dan kedalamannya merupakan beban belajar bagi peserta didik, muatan lokal, dan kegiatan pengembangan diri pada satuan pendidikan. Menurut Direktorat Pembinaan SMA (2010), kegiatan pengembangan diri merupakan kegiatan pendidikan di luar mata pelajaran 
Karim

sebagai bagian integral dari isi kurikulum sekolah. Kegiatan pengembangan diri merupakan upaya pembentukan watak dan kepribadian peserta didik yang dilakukan melalui kegiatan layanan konseling dan kegiatan ekstrakurikuler. Kegiatan ekstrakurikuler merupakan wadah yang disediakan oleh satuan pendidikan untuk menyalurkan minat, bakat, hobi, kepribadian, dan kreativitas peserta didik yang dapat dijadikan sebagai alat untuk mendeteksi talenta peserta didik.

Menurut Narmoatmojo (2010), ada 4 jenis kegiatan ekstrakurikuler, yaitu: (1) krida yang meliputi kepramu-kaan, latihan dasar kepemimpinan siswa (LDKS), palang merah remaja (PMR), pasukan pengibar bendera pusaka (PASKIBRAKA). (2) Karya ilmiah, meliputi kegiatan ilmiah remaja (KIR), kegiatan penguasaan keilmuan dan kemampuan akademik, dan penelitian. (3) Latihan/lomba keberbakatan/prestasi, yang meliputi pengembangan bakat olah raga, seni dan budaya, cinta alam, jurnalistik, teater, keagamaan. (4) Seminar, lokakarya, dan pameran/ bazar, dengan substansi antara lain karir, pendidikan, kesehatan, perlindungan HAM, keagamaan, seni budaya.

Melalui ekstrakurikuler siswa diarahkan memiliki karakter yang abadi dan universal seperti kejujuran, kedisiplinan, menghargai pluralisme, mempunyai empati dan simpati. Semua aspek ini akan sangat menunjang kesuksesan siswa kelak di masa mendatang.

Ada tiga peran utama dilaksanakannya kegiatan esktrakuri-kuler, yaitu: (1) memperdalam dan memperluas pengetahuan para siswa, (2) melengkapi upaya pembinaan, pemantapan, dan pembentukan nilai-nilai kepribadian para siswa, dan (3) membina serta meningkatkan bakat, minat, dan keterampilan yang memacu anak ke arah kemampuan mandiri, percaya diri, dan kreatif.

Adanya kegiatan ekstrakurikuler di sekolah diharapkan tidak mengganggu prestasi belajar siswa. Justru dengan siswa mengikuti kegiatan ekstrakurikuler, siswa sudah seharusnya mempunyai prestasi belajar yang memuaskan karena siswa mempunyai keseimbangan antara pendidikan 
Pengaruh Keikutsertaan Siswa dalam Bimbingan Belajar dan Ekstrakurikuler Terhadap Prestasi Belajar Matematika

formal yang menguras pemikiran dengan pendidikan yang sifatnya hiburan atau rekreasi.

SMA Negeri 2 Banjarmasin adalah salah satu sekolah menengah atas yang memiliki berbagai macam kegiatan ekstrakurikuler yang sangat diminati oleh siswa, diantaranya adalah OSIS, Basket, PMR, PASKIBRA, Karate, Jacs (komunitas pecinta Jepang), Volly, Futsal, KIR Kimia, Resma (Remaja Muslim Smada), Photography dan Pramuka. Kegiatan ekstrakurikuler tersebut telah memiliki jadwal tetap tiap minggunya, sehingga diharapkan siswa dapat memilih kegiatan esktrakurikuler yang sesuai dengan bakat dan minat mereka serta tidak mengganggu aktivitas belajar mereka.

Jika dikaitkan peran utama dari kegiatan esktrakurikuler dengan mata pelajaran matematika, maka karakter kemandirian, percaya diri, dan kreatif yang akan ditumbuhkan dan dikembangkan melalui kegiatan ekstrakurikuler tersebut sangat sesuai dengan tujuan diberikannya mata pelajaran matematika di SMA.

Selanjutnya, aktivitas belajar siswa merupakan hal yang sangat penting dalam meningkatkan prestasi belajar mereka dalam berbagai mata pelajaran. Hal itu tidak terkecuali untuk mata pelajaran matematika. Semakin sering siswa belajar maka akan memungkinkan siswa untuk mendapatkan prestasi belajar yang lebih baik.

Sering kita jumpai ada siswa yang tidak dapat belajar dengan baik sebagaimana mestinya sehingga prestasi belajar mereka tidak maksimal. Siswa yang demikian memerlukan bimbingan orang lain untuk dapat memahami materi pelajaran dengan baik. Terlebih mata pelajaran matematika yang selama ini dianggap sebagian besar siswa sebagai mata pelajaran yang dianggap “momok”. Menurut Prayitno (2004), bimbingan adalah proses pemberian bantuan yang dilakukan oleh orang yang ahli kepada seseorang atau beberapa orang individu, agar orang yang dibimbing dapat mengembangkan kemampuan dirinya sendiri dan mandiri. 
Karim

Bentuk bimbingan orang lain itu diantaranya adalah dengan menyediakan guru les atau mengikutsertakan siswa ke lembaga bimbingan belajar.

Sekarang ini banyak orang yang beranggapan bahwa bimbingan belajar dapat meningkatkan prestasi belajar siswa. Meskipun begitu, perlu juga disadari bahwa mungkin saja siswa yang ikut dalam bimbingan belajar itu hanya merasa terpaksa akibat adanya tuntutan orang tua yang tidak percaya bahwa pembelajaran di sekolah mampu membawa anak mereka bisa lebih berprestasi, yang secara tidak langsung hal ini akan menyita waktu yang berakibat membuat siswa merasa kelelahan sehingga mengakibatkan prestasi mereka menurun.

Hasil penelitian Djafri (2008) menunjukkan bahwa ekstrakurikuler di sekolah dapat meningkatkan prestasi belajar siswa. Sedangkan hasil penelitian Sukirman (2010) menunjukkan bahwa ada korelasi positif yang signifikan antara bimbingan guru dengan prestasi belajar Fisika siswa kelas XI IPA.

Berdasarkan uraian di atas, perlu dilakukan penelitian yang berkaitan dengan pengaruh bimbingan belajar dan kegiatan ekstrakurikuler terhadap prestasi belajar matematika siswa. Oleh karena itu, tujuan penelitian ini adalah untuk mengetahui pengaruh bimbingan belajar dan kegiatan ekstrakurikuler terhadap prestasi belajar matematika siswa.

\section{Metode Penelitian}

Metode penelitian yang digunakan adalah metode deskriptif. Penelitian ini akan mendeskripsikan hubungan sebab akibat antara kelompok siswa yang mengikuti kegiatan esktrakurikuler (eskul) dengan yang tidak dan antara kelompok siswa yang mengikuti bimbingan belajar (bimbel) dengan yang tidak terhadap hasil belajar matematika siswa.

Penelitian dilaksanakan pada SMA Negeri 2 Banjarmasin. Subjek dari penelitian ini adalah siswa kelas XI Jurusan IPA dan Jurusan IPS. Kelas XI Jurusan IPA terdiri dari 4 kelas paralel dengan jumlah siswa 144 orang. 
Pengaruh Keikutsertaan Siswa dalam Bimbingan Belajar dan Ekstrakurikuler Terhadap Prestasi Belajar Matematika

Sedangkan kelas XI Jurusan IPS terdiri dari 5 kelas paralel dengan jumlah siswa 155 orang.

Teknik pengumpulan data menggunakan teknik dokumentasi dan angket. Data yang terkumpul dianalisis dengan menggunakan analisis regresi dengan variabel bebas dummy.

Variabel bebas dalam penelitian ini adalah kegiatan esktrakurikuler (eskul) dan bimbingan belajar (bimbel). Eskul bernilai 0 jika siswa tidak mengikuti kegiatan eskul dan bernilai 1 jika siswa mengikuti eskul. Bimbel bernilai 0 jika siswa tidak mengikuti bimbel dan bernilai 1 jika siswa mengikuti bimbel. Sedangkan variabel terikat adalah prestasi belajar matematika siswa (Y). Model umum regresi dengan variabel dummy dari masalah di atas adalah $\hat{y}=a+b_{1}$ eskul $+b_{2}$ bimbel

\section{Hasil dan Pembahasan}

Jumlah siswa kelas IX Jurusan IPA sebanyak 144 orang. Prestasi belajar siswa untuk kelas XI Jurusan IPA berdasarkan keikutsertaan mereka dalam bimbingan belajar dan ekstrakurikuler dinyatakan dalam tabel 1 berikut ini.

Tabel 1. Prestasi Belajar Matematika Kelas XI Jurusan IPA

\begin{tabular}{|l|c|c|}
\hline \multicolumn{1}{|c|}{ Keikutsertaan Siswa } & BanyakSiswa & Rata-Rata \\
\hline Mengikuti eskul & 87 & 55,81 \\
Tidak Mengikuti eskul & 57 & 48,77 \\
Mengikuti bimbel & 55 & 64,46 \\
Tidak Mengikuti bimbel & 89 & 45,96 \\
Mengikuti eskul \& bimbel & 37 & 65,27 \\
Tidak Mengikuti eskul \& bimbel & 39 & 42,31 \\
\hline
\end{tabular}


Karim

Jumlah siswa kelas IX Jurusan IPS sebanyak 155 orang. Prestasi belajar siswa untuk kelas XI Jurusan IPS berdasarkan keikutsertaan mereka dalam bimbingan belajar dan ekstrakurikuler dinyatakan dalam tabel 2 berikut ini.

Tabel 2. Prestasi Belajar MatematikaKelas XI Jurusan IPS

\begin{tabular}{|l|c|c|}
\hline \multicolumn{1}{|c|}{ Keikutsertaan Siswa } & $\begin{array}{c}\text { Banyak } \\
\text { Siswa }\end{array}$ & Rata-Rata \\
\hline Mengikuti eskul & 91 & 66,73 \\
Tidak Mengikuti eskul & 64 & 50,80 \\
Mengikuti bimbel & 55 & 68,08 \\
Tidak Mengikuti bimbel & 100 & 39,92 \\
Ikut eskul \& bimbel & 47 & 71,06 \\
Tidak Mengikuti eskul \& bimbel & 56 & 39,73 \\
\hline
\end{tabular}

Hasil analisis regresi pada kelas XI Jurusan IPA adalah:

$$
\hat{y}=43,11+5,07 \text { eskul }+19,94 \text { bimbel }
$$

$(0,000) \quad(0,000)$

dengan $\mathrm{R}^{2}=35,5 \%$

Model regresi di atas signifikan untuk tingkat signifikansi $\alpha=5 \%$. Berdasarkan model regresi yang diperoleh dapat diketahui bahwa bimbingan belajar dan kegiatan ekstakurikuler mempunyai pengaruh positif yang signifikan terhadap prestasi belajar matematika bagi siswa kelas XI Jurusan IPA. Besar pengaruh bimbingan belajar dan kegiatan ekstrakurikuler terhadap prestasi belajar siswa sebesar 35,5\%.

Hasil analisis regresi pada kelas XI Jurusan IPS adalah:

$$
\hat{y}=39,29+26,17 \text { eskul }+5,09 \text { bimbel }
$$

$(0,000)$

$$
(0,003)
$$

dengan $\mathrm{R}^{2}=71,2 \%$

Sama halnya dengan model regresi untuk kelas XI Jurusan IPA, model regresi untuk siswa kelas XI Jurusan IPS juga signifikan untuk tingkat signifikansi $\alpha=5 \%$. Model regresi tersebut juga menunjukkan bahwa 
Pengaruh Keikutsertaan Siswa dalam Bimbingan Belajar dan Ekstrakurikuler Terhadap Prestasi Belajar Matematika

bimbingan belajar dan kegiatan ekstrakurikuler mempunyai pengaruh positif yang signifikan terhadap prestasi belajar matematika bagi siswa kelas XI Jurusan IPS. Besar pengaruh bimbingan belajar dan kegiatan ekstrakurikuler terhadap prestasi belajar siswa sebesar 71,2\%.

Hasil penelitian yang telah dikemukakan di atas menunjukkan bahwa terdapat pengaruh keikutsertaan siswa dalam bimbingan belajar dan keikutsertaan siswa dalam kegiatan ekstrakurikuler terhadap prestasi belajar matematika. Hasil ini didukung oleh rata-rata hasil belajar siswa seperti yang tertera pada tabel 1 dan tabel 2 . Hasil penelitian yang diperoleh sejalan dengan hasil penelitian yang telah dilakukan oleh Djafri (2008) dan Sukirman (2010).

Implikasi dari hasil penelitian ini adalah perlunya pemberian dukungan para guru dan pihak sekolah terhadap siswa yang mengikuti kegiatan bimbingan belajar maupun siswa yang mengikuti kegiatan ektrakurikuler.

\section{Kesimpulan}

Bimbingan belajar dan kegiatan ekstrakurikuler siswa mempunyai pengaruh positif yang signifikan terhadap hasil belajar matematika siswa di sekolah, baik untuk siswa jurusan IPA maupun siswa jurusan IPS.

\section{Daftar Pustaka}

Direktorat Pembinaan SMA. (2010). Juknis Penyusunan Program Pengembangan Diri Melalui Kegiatan Ekstrakurikuler di SMA. Jakarta: Depdiknas.

Djafri, N. (2008). Pengaruh Kegiatan Ekstrakurikuler Terhadap Prestasi Belajar Siswa pada Pesantren Al Khaerat Kota Gorontalo. INOVASI, Volume 5, Nomor 3, September 2008.

Narmoatmojo, W. (2010), Ekstra-kurikuler di Sekolah: Dasar Kebijakan dan Aktualisasinya. Tersedia: http://www. 
Karim

Prayitno. (2004). Dasar-dasar Bimbingan dan Konseling. Jakarta: Rineka Cipta.

Sukirman. (2010). Peranan Bimbingan Guru dan Motivasi Belajar dalam Rangka Meningkatkan Prestasi Belajar Peserta Didik. GUIDENA, Vol.1 No. 1 September 2011.

\section{Karim}

Universitas Lambung Mangkurat, Banjarmasin

E-mail: karim_unlam@hotmail.com 